\title{
Irish Priests in the Diocese of Quebec in the Nineteenth Century
}

\section{Marianna O'Gallagher}

Volume 50, numéro 2, 1983

Bilan de l'histoire religieuse au Canada

Canadian Catholic History: A survey

URI : https://id.erudit.org/iderudit/1007213ar

DOI : https://doi.org/10.7202/1007213ar

Aller au sommaire du numéro

Éditeur(s)

Les Éditions Historia Ecclesiæ Catholicæ Canadensis Inc.

ISSN

0318-6172 (imprimé)

1927-7067 (numérique)

Découvrir la revue

Citer cet article

O'Gallagher, M. (1983). Irish Priests in the Diocese of Quebec in the Nineteenth Century. Sessions d'étude - Société canadienne d'histoire de l'Église catholique, 50(2), 403-413. https://doi.org/10.7202/1007213ar

Tous droits réservés @ Les Éditions Historia Ecclesiæ Catholicæ Canadensis Inc., 1983
Ce document est protégé par la loi sur le droit d'auteur. L'utilisation des services d'Érudit (y compris la reproduction) est assujettie à sa politique d'utilisation que vous pouvez consulter en ligne.

https://apropos.erudit.org/fr/usagers/politique-dutilisation/ 


\title{
Irish Priests in the Diocese of Quebec in the Nineteenth Century
}

\author{
by Marianna O'Gallagher, S.C.H.
}

St. Patrick's High School, Quebec City

Like many another story, the history of Irish priests in Quebec has clouded beginnings. Who, for instance, were Fathers Cannon and Cliche of the French Regime? Was the Franciscan Cliche really McClish? His mother's name was Dunkin. The story of an Irish Franciscan on board d'Tberville's ship in his famous Hudson's Bay battles is another tantalizing green wisp among the strands of Canadian history.

During the days of Bishops Desgluy and Hubert, when priests were needed, there was great reluctance to receive Irish or English priests in Quebec because "their mentality is different from French Canadians." Irish priests were of course received without hesitation for the Maritimes. With the rising tide of European immigration into Canada, as will be seen, that attitude of reluctance in Quebec changed and Irish priests were accepted, welcomed, indeed sought after by the Bishops of Quebec.

Most of the studies published, and lectures offered, dealing with Irish, English or Scottish priests, trained and ordained in Quebec or connected with the Diocese, have been studies showing their work in the Maritimes or in Upper Canada, quite outside the geographical province of Quebec. In this paper I wish to touch on some of the story of the Irish Priests who stayed in the heart of the diocese of Quebec, in territorial Quebec.

The vast diocese of Quebec at its greatest extent reached the Gulf of Mexico, Hudson's Bay and the Rockies. From the city of Quebec went out, if not the missionaries themselves, at least the commission to the priests to organize and administer the territories that would eventually become subdivided into the parishes, then the dioceses, and again eventually be reunited into the ecclesiastical province. 
Before any division into dioceses occurred, or could even be considered, however, there was a long period of adjustment by the French Catholic colony under the new British administration. An important part of "the adjustment" occurred among the three elements of Anglican Church, Catholic Church and British government. The Anglican Bishop indicated that one Bishop for the colony was enough, and that that should be the Anglican bishop; the Catholic Church, at thai moment inconveniently without a Bishop, could not agrec. (Bishop Pontbriand had died in 1760.) The British administrators had to admit a dilemma. Their recognition of an established church would put them in the position of persecutors as well as conquerors if they were to enact what the British law allowed - impose Anglicanism on 60000 Roman Catholic French Canadians. It is my opinion that one of the factors that influenced the British administrators to a quiet compromise in this situation, was their experience in Ireland. Someone had realized that the more you push a people around, the tougher you act towards them, the stiffer the resistance becomes and the uglier in turn must be the measures taken to break down the resistance. Marked by their experience, the administrators sensed the parallel with Ireland and after long negotiations arrived at a pragmatic solution: Briand, the choice of the Chapter of Quebec as successor to the See, was consecrated Bishop, in France, with the unpublicized approval of British government officials. He returned to Canada with the title of "Superintendant of the Romish Church", but to the Catholics he was the Bishop. He was empowered sacramentally to carry out the fullness of the priesthood, and this was what mattered to the Catholic people of Canada. A later successor of Briand, Bishop Plessis in 1818 was made a member of the Legislative Council, with the title of "Bishop of the Roman Catholic Church of Quebec."

All of this is prelude to the Bishop of Quebec's far reaching interest, control, and finally power to solve the problem of providing priests for the sprawling diocese. There was a shortage of priests at the end of the eighteenth and beginning of the nineteenth century. After the Treaty of Paris, most of the members of the male religious orders had gone from the colony. The few left were aging. During the period of transition there were few young men being attracted to the priesthood. In 1790 there were 146 priests in Canada, for about 145000 Catholics. There had been a ban on the entry of priests from France after 1760 . After 1793 that ban was lifted. The French Revolution had sent about 8000 priests to Great Britain as refugees. At the invitation of the Bishop of Quebec and with the permission of the British government, fifty- 
one of those French priests came to Canada and forty of them stayed, mainly as professors in the classical colleges and in the major and minor seminaries, and in a few parishes. Even with that addition, there were in 1808 only 166 priests for 200000 people. '

While it appears that the number of priests was diminishing, the number of people was growing, as immigration added its masses to the naturally increasing populace. A steady small stream of immigration was frequently enlarged by great waves, like that of the Loyalists, among whose English, Irish, Scots, Welsh, German and Indian components there certainly were Catholics. By far the most telling immigration, as far as the Church was concerned, was that following the Napoleonic Wars. For more than thirty years following those wars a growing number of people from the British Isles found their way to the colonies. Most of them landed at Quebec City. That port had become important for the handling of timber. The timber trade had gradually replaced the fur trade as the basis of British North American economy. A system of transport for timber out from Quebec became a passenger system on the return trip from the British Isles. With very little interior change the timber ships became passenger carriers as immigrants scrambled for passage to the New World. At times of hardship in Europe the timber ship routine became an escape route for thousands. Travel conditions varied with the times, too, from mere discomfort and inconvenience to downright misery, disease and death, as in the migrations of 1832 and 1847. From Quebec City, beyond which the large sailing vessels could not go, the immigrants could travel by rail and steamship to Montreal, Ontario and to "the States."

Even a cursory examination of the immigration statistics reveals that the Irish were in the majority of the immigrants every year. A large number, probably the majority, were Catholics. While the mainstream of immigrants continued to the interior, many, particularly the Irish Catholics, stayed in Quebec City. There was seasonal work available in stevedoring and clerking for the timber companies. The City where the Catholic Church was visible evidently made them feel at home. In addition, land was available near the cities (of Quebec and of Montreal too). So it was that before the famine of 1847 there existed in both Quebec and Montreal, and on both sides of the Saint Lawrence River, communities and settlements that were predominantly

\footnotetext{
${ }^{1}$ Cf. Lemieux, L'Établissement de la Première Province Ecclésiastique au Canada, 1783-1844, Montréal, Fides, 1968.
} 
Irish. Valcartier and St. Catherine's, northwest of Quebec, Frampton and St. Malachie, St. Sylvester south of the city, and many other towns began with Irish farmers and soldiers obtaining land grants. Quite a number of villages were established between 1802 and 1840 .

Priests were needed to care for the people's needs in those settlements. In this day and age, when church affiliation and membership have ceased to hold the social importance that they had in colonial and later times, teachers of history have to supply their students with the aura and the atmosphere of a church-conscious age. Our literature (oral as well as written) has preserved some types for us: such as the Sunday School (only Protestants went to Sunday School), the Methodist choir and the pecking order of a society that fought for and against clergy reserves. Generally, a great deal of caricature and colour has gone from our lives. No longer are there the great figures to daunt, to challenge, or to cherish, in the form of "the Pastor", or "Father Rector Said"... The importance of the priest in sacramental life, the respect and awe in which the gift of priesthood was held, no longer hold our attention. The dimension of religion and church holds no longer a high priority among us. This was not the case in our past - and especially was this true of the Irish. Catholicism in Ireland was an identity, a sore one for sure, but cherished, defended and if necessary defended to the death.

The immigrants brought this integration of the church in their daily lives with them in their experience: all immigrants - not just Catholic immigrants. Crossing the ocean did not diminish their reliance upon the organized structure of the church; in some cases, it may have increased it. It was a simple matter to follow the leadership, or build a leadership, out of a priest or minister.

When the immigrants came they did have priests among them as the Bishops had hoped they would. But these priests were few. Many families came with a seminarian among them, son or brother, loathe to be left behind when kith and kin crossed the ocean. Father Patrick McMahon is an example of this. In 1818 his family group of almost 20 arrived at Quebec. He had done some of his studies for the priesthood at Carlow College in Ireland and he would continue these at St. Hyacinth in the province of Quebec.

The Bishop of Quebec could not however rely on this haphazard arrival of immigrant priests for the expanding Irish population in the 
cities, and in the new farming communities growing up in "les rangs." There was, therefore, an exchange of letters between the Bishops of Quebec and the Irish Bishops covering the transfer of men from one diocese to another. There were visits to Irish seminaries by Canadian Clerics and others to recruit men for Canada. The young seminarians who transferred into Quebec went to the classical colleges (at Nicolet, or St. Hyacinth or St. Anne de la Pocatière, at Montreal and Quebec) or into minor seminaries, then went to Quebec to complete their studies and be ordained. Montreal, Nicolet and Three Rivers in turn opened major seminaries later.

In these colleges the Irish boys were integrated with their French Canadian confrères, and were educated in French and Latin. Their letters to the Bishop are frequently in French. Since very few parishes could be labelled exclusively Irish parishes, these priests would eventually carry on a bi-lingual ministry.

Two interesting letters testify to the qualify of training offered in Quebec. Young men from the Maritimes went to Quebec, Bishop Fraser of Nova Scotia wrote:

Without flattery and to strengthen my assertion, I say coram Deo, that a French Canadian education for the Priesthood is and would be my choice of the choicest.

In March 1823 Bishop McEachern then assisting the Bishop of Quebec but later on, in 1829, the first Bishop of Charlottetown,. wrote to Bishop Plessis, of an ecclesiastical student

He wishes me to ordain him. But I have formed a fixed resolution that I will never lay hands on him, or any such, until he is first trained in some of your colleges in Canada.

The stories of these gallant, hardworking, often heroic men add another page and another aspect to the saga of the pioneers. For all their faults, there is a grandeur and a glory there, in the calling, and often in the man responding to the call. Not that they were all angels. It is not surprising in a list of 276 Irish born or Canadianborn Irish priests to find an occasional rogue or a rascal, a wanderer or a wastrel, a mischief maker or a madman. They are all there: the wanderings of the Dominican Father Charles French can be followed, as Bishops sent good priests after him to try to repair the scandal of his passing. The sad extravagant actions of Father Hugh McGuirk, a veteran of service at Grosse Ile in the terrible '47, who lived to be 
96: his last days are chronicled in the history of the church in northern New Brunswick. He went after his curate with an axe.

The priests never became rich men. They couldn't. Where their flocks were struggling for subsistence, money was not readily forthcoming. Frequently, they were paid in kind, for it was all they could do.

There are probably many letters similar to that sent in 1833 by Father John Caulfield O'Grady of Frampton to Bishop Panet complaining that the people were not paying what they had promised. He must have written in desperation, and mailed the letter anyway though he expressed his realization that he could not expect more:

The majority of the inhabitants of the township live in a state of extreme poverty. They have barely enough land cultivated to furnish themselves with potatoes. In general once the farmers have cultivation done they are forced to work in town, to earn something to enable them to survive the winter.

(AAQ F 1-10 Fr. J.C. O’Grady to Bishop 9, 1833)

In telling stories like this I am not unaware of the two extremes that are often used to caricature both Irish Catholic and French Canadian society: the epithet "priest-ridden society" or the opposite accusation "anti-clericalism." These two terms are too easily bandied about by those who are out of tune with the actuality of any given situation or are unconscious of the ambivalence present in any strongflavoured society.

Neither am I unaware of the rivalries that later arose, and the fears generated over whether the Canadian Church would be French or Irish in its hierarchy. In presenting this small segment of the history of the Church I am attempting to recapture the 'spiritual ecology' of a period, to recapture the religious psyche of an age, and I wish to indicate layers and pockets and streams of nineteenth century Quebec society that may have been more influential than we tend to realize.

It is possible to compile a list of 276 names of Irish priests of the nineteenth century diocese of Quebec. ${ }^{2}$ First of all, there are

\footnotetext{
${ }^{2}$ A list of Frish and Scots priest was compiled by Dermot J. O'Gallagher and is now in possession of the author.
} 
several bishops among the Irish born priests: Edmund Burke, William Dollar, Patrick Phelan, John Sweeney to name but a few. Canadian-born sons of Irishmen became priests and bishops, too. Among these, my favorite is Bishop Edward John Horan, third bishop of Kingston. I like his story because he was the son of Gordian Horan of Quebec City, a man who served for many years as secretary of the committee of management of Saint Patrick's Church. His mother was Eleanor Cannon, sister of John, of the same committee. Bishop Edward Horan, when still a priest-teacher, is credited with initiating the Science Faculty of Laval University.

The Bishops are always easy to find, but it is the lives of the priests that this paper is meant to deal with. First and foremost for Quebec City was Father Patrick McMahon, the founder of Saint Patrick's Parish and the builder of Saint Patrick's Church. He came to Quebec in 1818 with a family group (about 20) and went to the Seminary of St. Hyacinth. He had already completed some of his clerical studies at Carlow College in Ireland. In 1822 he was ordained at Quebec City and appointed curate, one of many, at Notre Dame de Quebec, with the special care of the Irish as his apostolate. With the exception of a four years absence (in Saint John, N.B.) Father McMahon served his years of priesthood in Quebec. He gave 25 years to the people of Quebec City, and is remembered with a street named after him, but his memory is still better kept by the people of Saint Patrick's Church.

In 1828 Bishop Fenwick of Boston requested the Bishop of Quebec for McMahon to go to Boston. At a later time Bishop Bourget of Montreal proposed McMahon's name along with those of Aeneas McDonnell and Patrick Phelan for co-adjutor to Bishop Gaulin. (Phelan was chosen.) Evidently by that time, 1844, Bishop Lartigue's worry about Irish bishops preventing the establishment of an ecclesiastical province had been allayed.

Father Patrick McMahon's career in Quebec occurred during a time of change and excitement. In 1832 just before the laying of the cornerstone for the new church, the cholera epidemic that devastated the city broke out. Three thousand lives were lost. In 1834 there was another outbreak of cholera. This was also a period of very heavy immigration, and Quebec City received most of the immigrants. Since most of the immigrants were Irish, and most of the Irish were Catholics, McMahon was concerned with them. As a member of the Quebec Emigrant Society, a benevolent body of prominent citizens, he assisted in the 
direction of activities, but he was also active in his own right within his parish. His parishioners lived in every part of the city, and education and orphan care as well as the sacramental aspects of life occupied his attention.

His parishioners belonged to every stratum of society. In 1837 this became a source of trial for him, perhaps, and certainly a time of division in the parish. On Saint Patrick's Day, he preached a sermon, in which he called for blessings upon the government. His words were taken as approval of the administration (in those days the "Reformers" opposed the "Chateau Clique") and well they may have been, for the Chateau Clique was wooing the priests; others saw his words as support of the Reform cause. The newspapers, both French and English, carried letters complaining of clerical interference in lay matters, etc. etc. Worse than that however: a great public meeting of the parish was called and it resulted in a letter of approval signed by a good many who supported McMahon. Four members of the Committee of Management (Connolly, Donaghue, Quigley and Teed) were dismissed from that committee. Later on they were forgiven and they returned within a few years.

The position of Saint Patrick's parish in Quebec City was a unique one. The parish was accorded ceremonial privileges, as for instance, during the several years when Church Councils were held in Quebec. One day of the Councils' activities always appear to have been held at St. Patrick's Church with a special sermon preached for the occasion by one of the English speaking Bishops attending the Council. In 1847 at the time of the terrible famines in Ireland, Saint Patrick's with Father McMahon at its head spearheaded collections for the poor of Europe in the city. Later in the season when the immigrant victims of those famines began to swarm into the city Father McMahon sheltered the homeless in hastily constructed buildings around the church and followed that with donations of money to the orphanages in the city that were caring for Irish children.

When Father McMahon died in 1851 he was succeeded by Father James Nelligan. Like McMahon he was born in Ireland, ordained in Quebec (1830) and spent four years at the Basilica of Notre Dame de Quebec. Though a church existed for the Irish, it was at the Basilica that baptisms and marriages and funerals were held, and in the Basilica registers that the acts were recorded. Even when there was more than one priest assigned as chaplain at St. 
Patrick's, there would still be an Irish priest at the Basilica. It was only in 1856, when Nelligan's successor Father Bernard McGauran was chaplain at St. Patrick's that the Parish as such came into existence, and received its own registers.

Bernard McGauran came from Sligo, and arrived in Quebec with his mother and father, and perhaps a brother. He went to Saint Anne de la Pocatière to do his college studies. He was ordained in 1846 at age 35 by Bishop Signay. A year after ordination he was sent to Grosse Ile, in charge of the priests who were sent as chaplains to the sick and dying there, at the quarantine station that would see the arrival and death of thousands during that summer of sorrow. He himself fell sick with typhus, went to Quebec, recovered, and returned to the island. He was the last priest to leave the island that autumn. Father McGauran succeeded in 1856 to a parish that had begun well. He was able to continue the work of his predecessors, especially to see the canonical erection of the parish in his first year, and almost immediately the opening of Saint Brigid's Home to care of destitute old people of the city.

Priests like these are well remembered. Saint Patrick's Cemetery has fine monuments to McMahon and Mc Gauran. Not surprising for their years of work. However, across the pathway from the ten foot obelisk over Father McGauran's grave stands another very dignified three foot high stone dedicated to one Edward Holton, priest of the diocese of Ardagh who arrived in the summer of 1832 and died on September 21 ; the monument was raised by his "grateful countrymen." Powerful testimony to the respect for the priesthood, and the manners of another age.

Priests, both Canadian and Irish, created a reputation for themselves in Quebec that has become legendary. The outstanding event that evoked that heroicity and the consequent admiration was the terrible summer of 1847 when thousand of Irish, attempting to escape famine in Ireland sought refuge in Canada only to find here a grave. The eye of the storm of their misery was concentrated at Grosse Ile where a quarantine station had been set up to stop any epidemic from entering Canada with the immigrants. There on that little island in the St. Lawrence many priests, French Canadian and Irish (and Anglican too) laboured and died; or sickened, recovered and returned to work again with the faith-filled people for whom the presence of the priests meant a moment of happiness and a glimmer of hope. 
The priest cared for the dying and the dead, but they saw to the welfare of the living too. There were hundreds of children orphaned at this awful time. The priests became their custodians and gave them into the care of their parishioners, overcoming somehow the fear of sickness that was turning people away from the immigrants. It appears from the documents that the children were taken from Grosse Ile to Quebec City where at least two orphanages received them. The priests, under the direction of the Vicar General Cazeau, arranged for the children to be adopted in their own parishes. It is possible to trace the lives of several of these children, for example: Patrick and Thomas Quinn, 8 and 6 year old sons of James Quinn and Peggy Lyons from Lisanuffy in Roscommon. They were landed at Grosse Ile with their parents. Father Hubert Robson cared for the parents, and promised them, at their deathbeds that he would look after the boys. He himself fell sick and died, but his fellow priest, Father Luc Trahan, brought the children to Quebec and entered them in the orphanage on September 7, whence they were adopted by George Bourke of Nicolet on September 17. At Nicolet where many young Irish people were welcomed, the Quinn boys went to Miss Jane Marler's school. Eventually both boys went to the seminary and were ordained. Both men served various parishes, mainly in the Eastern township, and lived well into the twentieth century.

These few examples are typical of the steady band of men who followed each other in the ranks of the Irish clergy. There are many others, each worthy of his own monograph: John Brady, Patrick O'Dwyer, John Caulfield O'Grady, Bernard O'Reilley and William Moylan. The two latter had both served at Grosse Ile. Moylan later became a Jesuit and was rector of Fordham University in 1865. Others in the long list include William James McHarron, Francis McDonnell, Joseph Connelly, Simon Lawlor. These are only the names of those who served in Quebec, there are many others who went to Upper Canada or to the Maritimes after their ordination in Quebec.

In the immigrant experience it is the existence of a group that makes possible an easy, or at least a bearable transition to a new land. When the Irish group could rely upon the guidance of a spiritual leader, their parish priest who had been trained in the schools of the host country, and who was expected to serve as pastor to French Canadians as well as to 'his own people', then it is not surprising to find for the most part a process of neighbourliness and acceptance 
growing in the countryside of Quebec. There are exceptions. The French Canadians of a parish in Hull complained to their bishop that Father John Brady paid more attention to the Irish among his flock than to them. The Bishop wrote to Father John and told him to "share himself" with his parishioners. Exceptions nonetheless, the comfortable interchange that one was able to find in many parts of the province, between Irish and French Canadian in the parishes, attests to the validity of this claim.

There are very few monuments to these workers in the vineyard. Here and there a street name stands out, McMahon Street in Quebec City, Maguire Avenue in Sillery. A church here and there has a plaque on its wall to honour its Irish founder. Occasionally one finds a picture in a parish rectory.

Perhaps the records published in this association's journals and in other modest pieces will bring to light the everyday deeds and the everyday influence of these everyday heroes of our Catholic past, and give them the recognition that is long overdue. 